\title{
OCENA PROPONOWANYCH ZMIAN W PRZEPISACH KODEKSU KARNEGO DOTYCZĄCYCH ŚRODKÓW ZABEZPIECZAJĄCYCH
}

\section{PODSTAWOWE ZALOŻENIA DOTYCZĄCE SANKCJI STOSOWANYCH WZGLĘDEM SPRAWCÓW NAJPOWAŻNIEJSZYCH PRZESTĘPSTW}

Pod koniec 2012 r. i na początku 2013 r. ukazały się na stronie internetowej Ministerstwa Sprawiedliwości dwa projekty zmian w przepisach prawa karnego poświęcone środkom zabezpieczającym ${ }^{1}$. Jednym z zagadnień objętych propozycjami nowelizacyjnymi była kwestia postępowania z niebezpiecznymi przestępcami, którzy jeszcze w latach osiemdziesiątych ubiegłego wieku popełnili poważne czyny karalne - przede wszystkim morderstwa. Wielu z nich orzeczoną karę śmierci zamieniono w 1989 r. na mocy ustawy amnestyjnej na karę 25 lat pozbawienia wolności. W nadchodzacych latach osoby te będa opuszczały zakłady karne. Pewna ich część, być może nawet większość z nich, wykazuje zaburzenia osobowości, niekiedy też otwarcie deklaruje, że popełni nowe przestępstwa². Aby przeciwdziałać temu niebezpieczeństwu, autorzy

${ }^{1}$ Pierwszy z tych projektów nosi w nagłówku datę 2 listopada 2012 r., drugi zaś datowany jest na 28 stycznia 2013 r. Projekt listopadowy został ponadto opatrzony obszernym, kilkudziesięciostronicowym uzasadnieniem. Wskazane tu projekty oraz uzasadnienie opublikowano na stronie internetowej Ministerstwa Sprawiedliwości: www.bip.ms.gov.pl/projekty-aktow-prawnych/prawo karne.

${ }^{2}$ Na gruncie psychologii i psychiatrii przez pojęcie zaburzeń osobowości rozumie się względnie trwałe zakłócenia i zahamowania (anomalie) jej rozwoju, przebiegające bez rozpadu struktury osobowości. Zaburzenia te dotyczą sfery emocjonalnej, charakterologicznej oraz popędowej. Do najważniejszych przejawów tych zaburzeń istotnych z punktu widzenia prawa karnego ponieważ prowadzą często do konfliktu z normami tej dziedziny prawa - należą niedojrzałość emocjonalna, brak poczucia winy i odpowiedzialności za swoje zachowania, słaba kontrola nad emocjami, niewykazywanie uczuć moralnych, minimalny wpływ kary na poprawę zachowania, brak wyrzutów sumienia, niezdolność do angażowania się w trwałe związki uczuciowe z innymi ludźmi, uchylanie się od dyscypliny, agresywność, brak lęku, nieumiejętność tworzenia dalekosiężnych planów oraz konsekwentnego ich realizowania, a także dążenie do natychmiastowego zaspokojenia potrzeb, często bez uwzględnienia interesów innych osób. Do niedawna tradycyjnie rozróżniano (część specjalistów czyni tak zresztą nadal) cztery podstawowe formy zaburzeń osobowości, tj. psychopatię, socjopatię, charakteropatię oraz homilopatię. Współcześnie odchodzi się w naukach medycznych i w psychologii od stosowania wymienionych tu pojecć jako niezbyt precyzyjnych, albo nawet zbyt wieloznacznych - jak w przypadku pojęcia psychopatii. Termin ten jest zastępowany np. określeniem osobowości nieprawidłowej lub dyssocjalnej, natomiast socjopatia 
zmian nowelizacyjnych postulowali wprowadzenie nowych rodzajów środków zabezpieczających, które miałyby zastosowanie do sprawców najpoważniejszych czynów zabronionych po odbyciu przez nich wieloletnich kar pozbawienia wolności ${ }^{3}$.

Zamierzenia te generalnie zasługują na uznanie i poparcie przede wszystkim dlatego, że obecna konstrukcję kar najsurowszych przewidziana w polskim prawie należy uznać za przestarzała, by nie powiedzieć archaiczną. Zapewne niewiele jest rozwiniętych krajów, w których przestępca skazany na dożywotnie pozbawienie wolności może się ubiegać o przedterminowe zwolnienie z odbywania tej kary dopiero po 25 latach pobytu w więzieniu. Jeszcze mniejszy będzie krąg państw nowoczesnych, w których przepisach zawarta jest klauzula podobna do treści art. $77 \S 2$ k.k., a mianowicie, że sąd według własnego uznania może w szczególnie uzasadnionych wypadkach obostrzyć kryteria warunkowego, przedterminowego zwolnienia z odbywania kary pozbawienia wolności. Nieraz już zdarzało się, że na podstawie tego przepisu sądy, wymierzając karę za morderstwa, zastrzegały w wyroku, że skazany może się ubiegać o warunkowe zwolnienie po minimum 40, a nawet 45 latach odbywania kary. Tego typu praktykę należy uznać za bardzo kontrowersyjnąwydaje się, że jest ona sprzeczna z treścią art. 3 k.k., wyraźnie przewidującego, że kary stosuje się z uwzględnieniem zasady humanitaryzmu ${ }^{4}$. Trudno uznać za przejaw tej zasady sytuację, w której np. osoba skazana na karę dożywotniego pozbawienia wolności (jeśli ma więcej niż 40 lat w momencie wydawania wyroku) praktycznie nie ma szans na wyjście na wolność, jeżeli są obostrzył jej czasowe kryteria opuszczenia zakładu karnego we wskazany wyżej sposób. Taka praktyka musi razić jeszcze bardziej, jeżeli uwzględnić, że według niektórych poglądów występujących na gruncie psychiatrii i psychologii osoby wykazujace dyssocjalne zaburzenia osobowości nie sa w stanie powstrzymać się od popełnienia czynu karalnego, jak również nie zawsze potrafią uświadomić sobie całokształt społecznych skutków swojego zachowania w sposób właściwy dla jednostki niezaburzonej osobowościowo ${ }^{5}$.

zyskała nazwę antyspołecznych zaburzeń osobowości. Zaburzenia osobowości nie są zaliczane do chorób psychicznych, nie stanowia też formy upośledzenia umysłowego. Zazwyczaj psychopaci i socjopaci reprezentuja zwykły, a nawet ponadprzeciętny stopień rozwoju intelektualnego. Tylko wyjątkowo, w szczególnych przypadkach zaburzenia te sa traktowane jako ,inne zakłócenia czynności psychicznych" w rozumieniu art. $31 \S 1$ k.k. W takiej nadzwyczajnej sytuacji moga one prowadzić do ustalenia ograniczonej poczytalności, a zupełnie wyjątkowo - nawet do niepoczytalności. Por. w tym względzie: A. Lipczyński, Psychologia sqdowa, Warszawa 2007, s. 95; M. Cieślak et al., Psychiatria w procesie karnym, Warszawa 1991, s. 212-217; M. Ciosek, Psychologia sadowa $i$ penitencjarna, Warszawa 2003, s. 203-204; A. Bilikiewicz, J. Lewandowski, P. Radziwiłowicz, Psychiatria, Warszawa 1999, s. 184; K. de Walden-Gałuszko, Zarys psychopatologii ogólnej i psychiatrii, Gdańsk 1999, s. 53; B. Pastwa-Wojciechowska, Naruszanie norm prawnych w psychopatii. Analiza kryminologiczno-psychologiczna, Gdańsk 2004, s. 29-31; K. Pospiszyl, Psychopatia, Warszawa 1985, s. 6-18 i 101-102.

${ }^{3}$ J. M. Ferenz, Niebezpieczni sprawcy: izolacja, leczenie, nadzór, „Na Wokandzie” 2013, nr 2, s. 18.

${ }^{4}$ Por. M. Bojarski, Środki związane z poddaniem sprawcy próbie, w: M. Bojarski (red.), J. Giezek, Z. Sienkiewicz, Prawo karne materialne. Część ogólna i szczególna, Warszawa 2010, s. 360; J. Warylewski, Prawo karne. Część ogólna, Warszawa 2007, s. 429-430 i 457.

${ }^{5}$ Zob. w tym względzie J. Przybysz, Psychiatria sqdowa. Opiniowanie w procesie karnym, Toruń 2003. Autor ten w cytowanej pozycji wskazuje m.in.: „Niewątpliwie opiniowanie poczy- 
Obowiązujący obecnie w Polsce system sankcji karnych stosowanych względem osób, które dopuściły się najpoważniejszych przestępstw, powinien zostać przekształcony - i z pewnością zostanie w przyszłości zmieniony - nie pasuje on bowiem do współczesnych standardów stosowanych w tym zakresie w krajach zachodnich. Czemu bowiem ma służyć przetrzymywanie osoby skazanej - nawet za morderstwo - w więzieniu przez okres dłuższy niż 10-15 lat? W zakresie działań resocjalizacyjnych jest to okres wystarczajacy, by odpowiednio wpłynąć na zmiany osobowościowe takiej osoby. Oczywiście można by powiedzieć, że dłuższe niż wymienione okresy pobytu w zakładzie karnym są konieczne ze względu na cel sprawiedliwościowy kary. Ale jeżeli rzeczywiście brać pod uwagę ten czynnik, to wówczas wobec zabójcy należałoby stosować karę śmierci lub bezwzględnego dożywocia. Jeżeli natomiast te formy kary zostały odrzucone, oznacza to również zgodę na to, aby kara - nie będąc formą odwetu odzwierciedlającego ciężar wyrządzonej szkody - była do tej szkody proporcjonalna. Tę proporcję można ustalać na różne sposoby: można wyznaczyć za morderstwo górna granice kary np. 10 lub 15 albo 20 czy 25 lat pozbawienia wolności. Niemniej wciąż pozostaje wówczas aktualne pytanie: W jakim celu trzymać w więzieniu człowieka, który został poddany procesowi resocjalizacji, przebywa tam już kilkanaście lat i okaże się, że nic więcej na polu poprawy - zarówno jurydycznej, jak i moralnej - z nim zrobić się nie da? Czy zatem izolowanie kogoś w zakładzie karnym - nawet za ciężkie przestępstwo - przez 40 lat będzie bardziej odpowiadało wymogom sprawiedliwości, niż przetrzymywanie go w tym miejscu przez np. 20 lat? Jest to watpliwe, natomiast jest rzeczą pewna, że po upływie około 10 lat przebywania w zakładzie karnym zachodzą w psychice więźnia nieodwracalne zmiany, które bardzo utrudniaja, a nawet niekiedy uniemożliwiają mu powrót do życia w społeczeństwie $^{6}$.

W kulturze europejskiej kara, zgodnie z wzorcami chrześcijańskimi, ale i nie tylko z nimi, wiąże się z odpłatą i zapłatą za czyn. Jej istotna cecha wyróżniająca jest konieczność naprawienia przez sprawcę szkody lub zapłaty odszkodowania oraz odpokutowanie, jak również wyrażenie skruchy za swój czyn. Przestępca powinien zatem - zarówno w przenośni, jak i dosłownie zapłacić za to co zrobił, ale musi on mieć również z a w s z e szansę na realny, a nie tylko teoretyczny, powrót do społeczeństwa ${ }^{7}$. Dlatego też sprawcy nawet najpoważniejszych zbrodni, jeżeli tylko nie są dotknięci zaburzeniami psychicznymi lub osobowościowymi i w okresie pobytu w zakładzie karnym

talności sprawców z osobowością zaburzoną może nasuwać liczne wątpliwości natury etycznej. Mimo to przyjmuje się w opiniowaniu prymat ochrony społecznej nad niepełnowartościowością psychiczną tych osób. Wynika to głównie z braku skutecznych metod ich rehabilitacji i resocjalizacji - nie znajdujemy innego sposobu ochrony społeczeństwa przed ich przestępczą działalnością niż izolacja w zakładach karnych. Po drugie opiniowanie poczytalności ograniczonej w odbiorze sprawców byłoby odbierane jako atrybut bezkarności” (ibidem, s. 173). Por. E. Habzda-Siwek, Diagnoza stanu psychicznego sprawcy $w$ procesie karnym, Kraków 2002, s. 132; K. Pospiszyl, op. cit., s. 37 .

${ }^{6}$ M. Ciosek, op. cit., s. 218 i s. 223. Por. J. Błachut, A. Gaberle, K. Krajewski, Kryminologia, Gdańsk 1999, s. 486.

7 Utrata nadziei na powrót do życia na wolności stanowi nierzadko u więźniów długoterminowych przyczynę chorób psychicznych. Zob. M. Ciosek, op. cit., s. 223. 
wykazują poprawę po odbyciu długoterminowej kary pozbawienia wolności, powinni mieć szansę na rozpoczęcie nowego życia w społeczeństwie.

Jeżeli natomiast przestępca skazany za czyny o znacznym ładunku społecznej szkodliwości, dokonane z użyciem przemocy, wykazuje przy tym objawy w zakresie schorzeń psychicznych lub osobowościowych bądź dotknięty jest zaburzeniami w sferze popędu seksualnego, to po odbyciu kary powinien być kierowany tytułem środka zabezpieczającego do specjalnego zakładu zamkniętego albo należałoby go objąć szczególnym nadzorem po wyjściu na wolność. Czas trwania tych środków nie powinien być z góry określony - sprawca w tym czasie byłby poddany kontroli w zakresie swoich zachowań, a jednocześnie powinna być mu udzielona pomoc, tak aby ponownie nie dopuścił się czynu karalnego ${ }^{8}$. Gdyby nadzór okazał się nieskuteczny, osoba taka mogłaby zostać umieszczona tytułem środka zabezpieczającego w zakładzie zamkniętym. Część najbardziej niebezpiecznych przestępców mogłaby trafić do zakładu zabezpieczającego od razu po odbyciu kary z pominięciem zastosowania wolnościowego środka ochronnego.

Tak w dużym skrócie rysuje się ogólna koncepcja sankcji ochronnych stosowanych względem osób skazanych za najpoważniejsze przestępstwa. Jak na tym tle przedstawiają się zatem propozycje Ministerstwa Sprawiedliwości w zakresie nowych środków zabezpieczających?

\section{NOWE POSTPENALNE ŚRODKI ZABEZPIECZAJACE STOSOWANE WOBEC SPRAWCÓW WYKAZUJĄCYCH ZABURZENIA OSOBOWOŚCIOWE}

Treść obu omawianych tu projektów jest naznaczona dążeniem ustawodawcy do podkreślenia różnic pomiędzy nową formą izolacyjnego środka zabezpieczającego przeznaczonego dla przestępców z zaburzeniami osobowości a sankcjami karnymi. Niewątpliwie wpływa to na złożoność i skomplikowanie proponowanych rozwiązań, a także niepełną ich spójność z istniejącymi już uregulowaniami w Kodeksie karnym.

W uregulowaniach projektu nowelizacyjnego z 2 listopada 2012 r. pojawił się środek ochronny, zamieszczony w nowym przepisie art. 95b k.k., polegający na umieszczeniu w zakładzie karnym, w którym stosuje się specjalne środki lecznicze lub rehabilitacyjne w stosunku do przestępców wykazujących zaburzenia osobowości ${ }^{9}$. Dalsza część uregulowań tej instytucji została zawar-

8 Powinny jednak istnieć ustawowe ograniczenia czasowe zarówno w zakresie nadzoru ochronnego stosowanego względem osoby na próbę zwolnionej z zakładu, w którym był wykonywany środek zabezpieczający, jak też maksymalnego terminu internacji w takim zakładzie. Stosowanie środków ochronnych nie może przecież trwać w nieskończoność.

9 Projektowany art. 95b k.k. otrzymał następujące brzmienie: ,,Jeżeli sprawca został skazany na karę pozbawienia wolności bez warunkowego jej zawieszenia za przestępstwo przeciwko życiu, zdrowiu, bezpieczeństwu powszechnemu lub wolności seksualnej, popełnione w związku z zaburzeniem osobowości o takim charakterze i nasileniu, że zachodzi wysokie ryzyko popełnienia przez sprawcę podobnego przestępstwa, sąd orzeka umieszczenie sprawcy podczas odbywania kary w zakładzie karnym, w którym stosuje się szczególne środki lecznicze lub rehabilitacyjne”. 
ta w projektowanych przepisach Kodeksu karnego wykonawczego. W treści art. 83a $§ 1$ noweli do k.k.w. wskazano, że jeżeli w czasie odbywania kary pozbawienia wolności skazany będzie w dalszym ciagu wykazywał zaburzenia osobowościowe istotnie zagrażając życiu, zdrowiu lub wolności seksualnej innych osób, to osoba ta w okresie 6 miesięcy przed zakończeniem odbywania kary lub warunkowym przedterminowym zwolnieniem musiałaby się poddać badaniom psychologicznym i psychiatrycznym, przeprowadzanym co najmniej dwukrotnie. Jeżeli chociażby jedna z opinii psychiatrycznych wskazywałaby na występowanie u skazanego zaburzeń osobowości powodujących poważne niebezpieczeństwo dla życia, zdrowia lub wolności seksualnej innych osób, to dyrektor zakładu karnego przekazywałby opinie do sądu opiekuńczego z wnioskiem o umieszczenie skazanego (po odbyciu przezeń kary) w zakładzie zamkniętym tytułem środka zabezpieczającego. Dopełnienie tych unormowań projektodawcy zamieścili w ustawie o ochronie zdrowia psychicznego ${ }^{10}$. Nowe przepisy tego aktu prawnego - a mianowicie art. 49a i 49b - dawałyby możliwość internowania zaburzonych osobowościowo przestępców opuszczających więzienia w zakładach psychiatrycznych.

W treści art. 49d noweli do ustawy o ochronie zdrowia psychicznego znalazło się postanowienie, że osobę, którą umieszczono w zamkniętym zakładzie psychiatrycznym obejmuje się odpowiednim postępowaniem leczniczym, terapeutycznym lub rehabilitacyjnym, którego celem jest poprawa jej stanu zdrowia i zachowania w stopniu pozwalajaccym na powrót do życia w społeczeństwie i dalsze leczenie w warunkach poza zakładem.

Zasady, na jakich możliwe byłoby zwolnienie z internacji w tym zakładzie, uregulowano w art. 49e i 49f nowelizacji tego aktu prawnego. Mianowicie osoba umieszczona w zakładzie psychiatrycznym raz na 6 miesięcy mogłaby składać do sądu opiekuńczego wnioski o wydanie przez psychiatrów opinii $\mathrm{w}$ przedmiocie potrzeby jej dalszego pobytu na terenie tej instytucji. Natomiast nie rzadziej niż co 12 miesięcy sąd ten musiałby z urzędu zbadać, czy nie ustała potrzeba umieszczenia tej osoby w zakładzie psychiatrycznym, zasięgając opinii kierownictwa tej placówki oraz uwzględniając wyniki postępowania leczniczego, terapeutycznego i rehabilitacyjnego.

Omawiany projekt przewidywał też szerokie zastosowanie nowych, wolnościowych środków zabezpieczających w postaci dozoru policji (art. 98b k.k.) oraz elektronicznej kontroli miejsca pobytu sprawców czynów karalnych (art. 98c k.k.) po zakończeniu internacji ochronnej w zakładach zamkniętych. Dotyczyło to zarówno osób, które popełniły czyny zabronione w stanie niepoczytalności, w warunkach poczytalności ograniczonej, sprawców z zaburzeniami preferencji seksualnych, jak też przestępców wykazujacych zaburzenia osobowości. Wydaje się, że w razie naruszenia rygorów związanych z dozorem lub kontrolą elektroniczną sąd zajmujacy się sprawami karnymi mógłby ponownie zastosować internację takiej osoby w odpowiednim zakładzie zamkniętym. Jednakże ani art. 98b, ani też art. 98c projektu, poświęcone dozorowi policji oraz dozorowi elektronicznemu, nie wskazują skutków, jakie pociagnęłoby za sobą niezrealizowanie tych form dozoru przez osobę nim objęta. Kwestii tej nie rozstrzygają także pozostałe zapisy omawianych tu propozycji legislacyjnych.

${ }^{10}$ Ustawa o ochronie zdrowia psychicznego z 19 sierpnia 1994 r., Dz. U. Nr 111, poz. 535. 
Inaczej przedstawiają się propozycje zmienionych uregulowań karnoprawnych w projekcie nowelizacyjnym z 28 stycznia 2013 r. Kwestia nowego, izolacyjno-leczniczego środka zabezpieczającego realizowanego wobec przestępców zaburzonych osobowościowo została usunięta z unormowań zawartych w Kodeksie karnym. Regulacja dotycząca tej instytucji rozpoczyna się dopiero w treści przekształconych uregulowań Kodeksu karnego wykonawczego. Zgodnie z postanowieniami zawartymi w art. 83a projektu zmian w Kodeksie karnym wykonawczym każda osoba skazana, odbywająca karę pozbawienia wolności i wykazujacca przy tym zaburzenia p s y c h i c z n e mogłaby na wniosek dyrektora zakładu karnego zostać poddana izolacji po odbyciu tej kary w zakładzie zamkniętym w celu realizacji środka zabezpieczającego ${ }^{11}$. Zmienione zapisy ustawy o ochronie zdrowia psychicznego - podobnie jak w poprzednim projekcie - uprawniały by sąd opiekuńczy do rozpatrzenia wniosku dyrektora zakładu karnego w przedmiocie zastosowania postpenalnego środka izolacyjno-leczniczego ${ }^{12}$. Wprowadzono tu wszakże modyfikację polegająca na tym, że byłych więźniów umieszczano by w instytucjach o nazwie ,ośrodek terapii osobowości” lub w innych zakładach psychiatrycznych. Tak więc założono, że powstaną nowe typy zakładów psychiatrycznych specjalizujących się w terapii osobowości osób, które zakończyły odbywanie kary pozbawienia wolności ${ }^{13}$.

W treści zmienionych propozycji nowelizacyjnych skrócono termin zobowiązujący sąd do zbadania, czy istnieje dalsza potrzeba internacji przestępcy z zaburzeniami osobowościowymi. Zgodnie z art. 49g ustawy o ochronie zdrowia psychicznego sąd musiałby dokonać tej czynności nie rzadziej niż raz na 6 miesięcy. Z obowiązkiem tym zostało skorelowane zobowiązanie kierownika ośrodka terapii osobowości do przesyłania sądowi w okresach półrocznych opinii o stanie zdrowia osoby poddanej terapii oraz o postępach w jej leczeniu. Opinia taka musiałby zostać przesłana niezwłocznie, jeżeli kierownik ośrodka uznałby, że dalsze pozostawanie w nim internowanej jednostki nie jest konieczne.

11 Przepis art. 83a k.k.w. będący wynikiem proponowanej nowelizacji miałby otrzymać następującą treść: ,Jeżeli skazany, który odbywa karę pozbawienia wolności przejawia zaburzenia psychiczne o takim charakterze lub nasileniu, że zachodzi obawa popełnienia przez niego, po zwolnieniu z zakładu karnego, przestępstwa przeciwko życiu, zdrowiu, wolności seksualnej lub rozwojowi seksualnemu małoletnich, zwłaszcza gdy obawa taka jest uzasadniona z uwagi na charakter czynu uprzednio popełnionego przez skazanego, dyrektor zakładu karnego występuje z wnioskiem do właściwego sądu opiekuńczego o przeprowadzenie badań skazanego na podstawie ustawy z dn. 19. 08.1994 r. o ochronie zdrowia psychicznego".

$12 \mathrm{~W}$ art. 49a projektu zmian w ustawie o ochronie zdrowia psychicznego znalazło się następujące postanowienie: ,Sąd opiekuńczy właściwy dla siedziby zakładu karnego, po otrzymaniu wniosku, o którym mowa w art. 83a k.k.w., niezwłocznie wszczyna postępowanie w celu ustalenia, czy zachodzi konieczność umieszczenia osoby, której wniosek dotyczy bezpośrednio, w ośrodku terapii osobowości lub w innym szpitalu psychiatrycznym”.

${ }^{13}$ Wspomniana wcześniej niespójność nowych uregulowań prawnych z treścią obowiązujących przepisów Kodeksu karnego polega m.in. na tym, że projektowany art. 49e pkt 1 ustawy o ochronie zdrowia psychicznego zawarty w projekcie styczniowym stanowi, iż w ośrodku terapii osobowości będą umieszczane osoby wykazujące zaburzenia osobowości, jak również przestępcy z zaburzeniami preferencji seksualnych. Trudno określić, jak w kontekście tego uregulowania przedstawiać się będzie rola istniejących już i funkcjonujących na podstawie art. 95a k.k. zakładów dla osób skazanych za czyny karalne będące wynikiem dewiacji seksualnych. 
$\mathrm{W}$ projekcie styczniowym dokonano ponadto swoistego rozdzielenia nowych, wolnościowych środków zabezpieczających. Dozór policji oraz kontrola elektroniczna miejsca pobytu byłyby orzekane przez sąd karny względem osób, które zostały poddane izolacji zabezpieczającej z powodu czynów karalnych popełnionych w stanie niepoczytalności, poczytalności ograniczonej lub $\mathrm{w}$ związku z zaburzeniami preferencji seksualnych ${ }^{14}$. Środki te nie miałyby natomiast zastosowania do przestępców opuszczających ośrodki terapii osobowości. W tym wypadku bowiem, zgodnie z projektowanym art. $49 \S 1$ ustawy o ochronie zdrowia psychicznego, zwolnienie z tej placówki powinno mieć charakter warunkowy - na próbę. Okres tej próby nie mógłby być krótszy niż rok i nie dłuższy niż 5 lat. Jeżeli w tym czasie osoba wypisana z ośrodka nie stosowałaby się do obowiązków nałożonych na nią przez sąd (tzn. nie poddała się leczeniu na wolności lub naruszałaby warunki kontroli miejsca pobytu i zatrudnienia), sąd opiekuńczy mógłby ponownie umieścić taką osobę w zakładzie psychiatrycznym w celu kontynuacji terapii osobowości w warunkach społecznej izolacji.

\section{OCENA PROPONOWANYCH ROZWIĄZAŃ NOWELIZACYJNYCH}

Jak już wcześniej podkreślono, na konstrukcji normatywnej obu omawianych tu projektów nowelizacji Kodeksu karnego i innych aktów prawnych zaważyła koncepcja zastosowania nowych postpenalnych środków zabezpieczających przede wszystkim w stosunku do sprawców okrutnych zbrodni, którym karę śmierci zamieniono na karę 25 lat pozbawienia wolności ${ }^{15}$. Za główny cel nowych regulacji ich twórcy postawili sobie ochronę społeczeństwa przed tymi właśnie niebezpiecznymi jednostkami i założenie to determinuje cały układ proponowanych rozwiązań. Ponieważ projektodawcy obawiali się zarzutów, że nowe postpenalne środki zabezpieczające faktycznie będą stanowiły dla zaburzonych osobowościowo przestępców formy represji karnej, starali się stworzyć unormowania wyraźnie odróżniające te nowe instytucje nie tylko od kar, ale w ogóle od sankcji karnych. Autorzy omawianych tu zmian w prawie karnym starali się uniknać posądzenia o to, że wprowadzenie i stosowanie nowych instytucji naruszy zasadę lex retro non agit oraz nulla poena sine lege $e^{16}$. Nowe

${ }^{14}$ Kwestii tej został poświęcony projektowany art. 98a k.k., który stanowi: „§ 1 Sąd może orzec w stosunku do sprawcy, o którym mowa w art. 94, art. 95 lub art. 95a § 1 k.k. dozór Policji lub elektroniczną kontrolę miejsca pobytu tytułem środka zabezpieczającego, jeżeli jest to konieczne ze względu na ochronę porządku prawnego. § 2 Dozór Policji orzeka się bez określenia terminu; sąd uchyla dozór, jeżeli dalsze jego stosowanie nie jest konieczne. Elektroniczną kontrolę miejsca pobytu orzeka się na czas nie przekraczajacy 5 lat".

${ }^{15} \mathrm{~W}$ doniesieniach prasowych, odwołujacych się do opinii o projekcie omawianej tu ustawy nowelizacyjnej wydanej przez Radę Legislacyjna, jest mowa o „18 niebezpiecznych przestępcach oraz ewentualnie innych pojedynczych przypadkach”. Zob. A. Łukaszewicz, Bezmyślna amnestia ma kosztować 340 milionów złotych, ,Rzeczpospolita” z 27 czerwca 2013 r., s. C1.

16 J. M. Ferenz, op. cit., s. 19. 
środki zabezpieczające nie były przecież przewidziane $\mathrm{w}$ uregulowaniach prawnych w czasie, gdy osoby, do których miałyby one znaleźć zastosowanie, dopuszczały się zbrodni, za które wymierzono im karę śmierci. To zamierzenie projektodawców, aby wyraźnie odgraniczyć od sankcji karnych postpenalny zabezpieczający środek o charakterze izolacyjno-leczniczym wdrażany wobec osób zaburzonych osobowościowo, powoduje cały szereg komplikacji.

Zasadnicze zastrzeżenie wywołuje treściowe rozbicie całej regulacji, która została podzielona i rozmieszczona w trzech odrębnych aktach prawnych w Kodeksie karnym, w Kodeksie karnym wykonawczym oraz w ustawie o ochronie zdrowia psychicznego. Prowadzi to do nadmiernej złożoności i braku przejrzystości tej konstrukcji.

Przed omówieniem szczegółowych postanowień określonych we wskazanych propozycjach nowelizacyjnych należy stwierdzić, że zawarcie $\mathrm{w}$ projekcie z listopada 2012 r. wykonywania środka zabezpieczającego wobec przestępów zaburzonych osobowościowo w zakładzie karnym, oznacza powielenie krytykowanego w doktrynie uregulowania zawartego w art. 95 k.k. Chodzi tu o umieszczenie osób skazanych w zakładzie karnym, przy czym w okresie odbywania kary pozbawienia wolności ma być realizowany w stosunku do nich środek zabezpieczający. Wobec tego typu rozwiąania sa w doktrynie prawa karnego formułowane różnorodne zarzuty natury teoretycznej, a najistotniejszy z nich sprowadza się do wniosku, że w istocie brak tu różnicy w stosunku do terapeutycznego trybu odbywania kary pozbawienia wolności ${ }^{17}$. Zamiast więc wykreślić treść art. 95 k.k. i ewentualnie wprowadzić w to miejsce inna formę środka ochronnego realizowanego względem osób o poczytalności ograniczonej, projektodawcy zamierzali zamieścić w Kodeksie karnym jeszcze jedną instytucję o podobnej, wadliwej konstrukcji.

Po odbyciu kary pozbawienia wolności przestępca wykazujacy zaburzenia osobowości na wniosek dyrektora zakładu karnego mógłby zostać umieszczony w zakładzie psychiatrycznym na mocy orzeczenia sądu opiekuńczego. Wątpliwości może tu budzić zarówno oddanie kompetencji w tym zakresie w ręce sądu opiekuńczego, nie zaś sądu karnego, jak również umieszczanie tego typu sprawców w zakładach psychiatrycznych. Do tych dwóch kwestii wypadnie za chwilę jeszcze powrócić.

Projekt listopadowy przewidywał także nazbyt szerokie - jak można sądzić - stosowanie wolnościowych środków zabezpieczających w postaci dozoru policji oraz elektronicznej kontroli miejsca pobytu dużej liczby osób opuszczających zakłady, w których stosowano wobec nich środki zabezpieczające. Środki te miał orzekać sąd karny, co powodowało kolejny problem, ponieważ taka regulacja godziła w założenie, że środki postpenalne nie będą wykazywały cech instytucji karnorepresyjnych. Gdyby postanowienia projektu listopadowego

${ }^{17}$ Por. w tym względzie: E. Bieńkowska, Środki zabezpieczajace, w: G. Rejman (red.), Kodeks karny, czesść ogólna. Komentarz, Warszawa 1999, s. 1267; L. Gardocki, Prawo karne, Warszawa 2002, s. 196; A. Kwieciński, Lecznicze środki zabezpieczajace w polskim prawie karnym i praktyka ich wykonywania, Wrocław 2009, s. 89 oraz s. 90-92; M. Tarnawski, Izolacyjno-lecznicze środki zabezpieczajace w ujęciu kodeksu karnego z 1997 r., w: A. J. Szwarc (red.), Rozważania o prawie karnym. Ksiega ku czci prof. A. Ratajczaka, Poznań 1999, s. 303; S. Lelental, Kodeks karny wykonawczy. Komentarz, Warszawa 2001, s. 513-514. 
weszły w życie, efekt byłby taki, że środek izolacyjno-leczniczy względem jednostek zaburzonych osobowościowo po odbyciu kary orzekałby sąd opiekuńczy, natomiast środki wolnościowe, po zwolnieniu z zakładu psychiatrycznego tj. dozór policji względnie kontrolę elektroniczną miejsca pobytu - sąd karny.

Wydaje się, że wskazane problemy projektodawcy dostrzegli i starali się fragmentarycznie skorygować rozwiąania mogące budzić zastrzeżenia. Niestety trzeba powiedzieć, że w projekcie nowelizacji unormowań prawnokarnych ze stycznia 2013 r. część istniejących problemów uległa jeszcze pogłębieniu.

Regulacja prawna nowego środka izolacyjno-leczniczego mającego zastosowanie do przestępców z zaburzeniami osobowości została całkowicie usunięta z treści Kodeksu karnego. Postanowienia dotyczące postpenalnego, izolacyjno-leczniczego środka zabezpieczajacego realizowanego względem tej grupy przestępców zamieszczono głównie w przepisach Kodeksu karnego wykonawczego oraz ustawy o ochronie zdrowia psychicznego, mimo że to właśnie kodeks karny jest miejscem najbardziej właściwym dla regulacji podstaw prawnych stosowania środków zabezpieczajacych.

Za również niezbyt udane należy uznać wskazanie zawarte w projekcie zmian Kodeksu karnego wykonawczego, iż z wnioskiem o zastosowanie postpenalnego, izolacyjno-leczniczego środka zabezpieczającego dyrektor zakładu karnego występuje w stosunku do skazanych przejawiajacych zaburzenia psychiczne. Wydaje się, że jest to określenie zbyt ogólne i nieprecyzyjne, mogące rodzić wątpliwości, czy chodzi tu przestępców z zaburzeniami osobowości. Z pewnością użyte w projekcie listopadowym określenie ,,sprawcy z zaburzeniami osobowości” było bardziej właściwe.

Nowe propozycje zmian w uregulowaniach poświęconych środkom zabezpieczającym tylko częściowo uwzględniły zarzuty, formułowane głównie przez lekarzy, że zakłady psychiatryczne nie sa najlepszym miejscem do internowania przestępców zaburzonych osobowościowo ${ }^{18}$. Zaproponowano zatem utworzenie dla nich specjalnych instytucji pod nazwa „ośrodków terapii osobowości”, dodając jednak, że tacy przestępcy mogą być umieszczeni w tych ośrodkach lub w innych zakładach psychiatrycznych. Wynika z tego, że ośrodki terapii osobowości stanowiłyby rodzaj wyspecjalizowanych zakładów psychiatrycznych, zajmujących się wąsko rozumianym leczeniem zaburzeń osobowości, a poza tym przestępców opuszczających więzienia będzie można umieszczać także w innych zakładach psychiatrycznych. Jeśli uwzględni się, że przestępcy ci wymagają zazwyczaj złożonych form oddziaływania resocjalizacyjnego, trudno jest zaakceptować takie rozwiąanie.

W treści projektu styczniowego inaczej też uregulowano kwestię postpenalnych, wolnościowych środków zabezpieczających. Dozór policji oraz elektroniczna kontrolę pobytu osób zwalnianych z zakładów psychiatrycznych (art. 94 k.k.), z zakładów karnych (art. 95) oraz z zakładów przeznaczonych dla jednostek z zaburzeniami preferencji seksualnych (art. 95a k.k.) orzekałby sad karny, natomiast w ustawie o ochronie zdrowia psychicznego przewidziano, że przestępcy zaburzeni osobowościowo zwalniani z internacji ochronnej zostali-

18 J. M. Ferenz, op. cit., s. 19. 
by zobowiązani przez sąd opiekuńczy do realizacji określonych obowiązków. Chodziłoby o podjęcie terapii na wolności oraz informowanie sądu o miejscu stałego pobytu i zatrudnienia. W razie nieprzestrzegania tych wymogów sąd opiekuńczy mógłby orzec o ponownym umieszczeniu takich osób w zakładzie zamkniętym w celu kontynuowania terapii w warunkach społecznej izolacji.

$\mathrm{Na}$ gruncie przedstawionych propozycji nowelizacyjnych można mnożyć pytania i wątpliwości. Czy sąd opiekuńczy powinien być uprawniony do oceny prognozy kryminologicznej dorosłego sprawcy - często wielu już - przestępstw? Czym innym przecież jest np. wiedza na temat osobowości osób chorych psychicznie, które nie naruszyły prawa, kierowanych do zakładów psychiatrycznych lub nieletnich sprawców czynów karalnych, z którymi sędziowie sądów opiekuńczych mają zazwyczaj do czynienia, a czym innym już analiza prognozy kryminologicznej osób skazanych, niekiedy wielokrotnie, za poważne przestępstwa, wykazujących przy tym zaburzenia osobowościowe ${ }^{19}$.

Można też zadać pytanie, jak wyobrażaja sobie autorzy wskazanych tu projektów nowelizacyjnych funkcjonowanie ośrodków terapii osobowości. Czy rzeczywiście, jak się proponuje, z przestępcami opuszczajacymi zakłady karne i izolowanymi w takich instytucjach miałaby być prowadzona wyłacznie terapia o charakterze psychiatrycznym? Z treści projektów zmian w Kodeksie karnym wynika bowiem, że ośrodki terapii osobowości funkcjonowałyby jako wyspecjalizowane zakłady psychiatryczne. Takie założenie należy uznać za oderwane od realiów dotyczących zakresu działań korekcyjnych względem przestępców wykazujacych zaburzenia osobowości. Zróżnicowane formy tych zaburzeń oraz ich odmienna etiologia sprawiaja, że konieczne jest podejmowanie w stosunku do tego typu osób zróżnicowanych form oddziaływań ${ }^{20}$. Psychiatrzy i psycholodzy wskazują tu istnienie wymogu łączenia terapii farmakologicznej (podawania np. leków psychotropowych) z psychoterapia indywidualną i grupowa ${ }^{21}$. Skuteczna okazuje się w określonych przypadkach terapia behawioralna. Może się jednak okazać, że zabiegi o typowo leczniczym charakterze będą wymagały uzupełnienia, a niekiedy może nawet zastapienia przez oddziaływania reedukacyjno-resocjalizacyjne przygotowane specjalnie dla tej grupy osób (np. w formie terapii praca lub terapii ruchem) ${ }^{22}$. W krajach zachodnich realizacja tego typu programów wobec psychopatów i socjopatów trwa długo - często jest to okres trwający od 4 do 8 lat $^{23}$. Nawet tak złożone formy oddziaływań nie gwarantują jednak sukcesu w postaci istotnego zmniejszenia się antyspołecznych właściwości osobowościowych danej osoby. Wówczas konieczne będzie prowadzenie z taką internowaną jednostką oddziaływań resocjalizacyjnych przez psychologów i wychowawców do momentu

${ }^{19}$ Zob. B. Pastwa-Wojciechowska, op. cit., s. 116.

${ }^{20}$ Inaczej np. będą się przedstawiać zabiegi korekcyjne stosowane do kategorii psychopatów impulsywno-kryminalnych, a inaczej czynności resocjalizacyjne realizowane względem grupy psychopatów kalkulatywnych (manipulatorów ). Zob. bliżej: K. Pospiszyl, op. cit., s. 16-18 i s. 33.

${ }^{21}$ A. Jakubik, Zaburzenia osobowości, w: A. Bilikiewicz et al. (red.), Psychiatria kliniczna, t. 2, Wrocław 2002, s. 614-615.

${ }^{22}$ Zróżnicowane formy oddziaływań leczniczo-resocjalizacyjnych wobec psychopatów, którzy popełnili czyny karalne, omawia K. Pospiszyl, op. cit., s. 118-206.

${ }^{23}$ A. Jakubik, op. cit., s. 615. 
osiagnięcia przez zaburzonego przestępcę wieku, w którym zwykle aktywność przestępcza obniża się samorzutnie w takim stopniu, że osoba ta przestaje istotnie zagrażać społeczeństwu ${ }^{24}$.

Następna kwestia wiąże się ze stopniem izolacji osób internowanych w tych zakładach oraz sposobem ich funkcjonowania. Projektodawcy wskazuja, że powstaną nowe zakłady o profilu izolacyjno-leczniczym. Ale przecież stworzenie kilku takich ośrodków będzie bardzo kosztowne. Należy wziać pod uwagę, że muszą się one znajdować w większych miastach lub w ich pobliżu, w przeciwnym razie bardzo trudno będzie zagwarantować takim ośrodkom stały dyżur specjalistów np. z zakresu psychologii, a także psychiatrii i seksuologii. W razie usytuowania tych ośrodków w dużych aglomeracjach miejskich należałoby zapewnić tym instytucjom właściwą ochronę, która poziomem zabezpieczenia zewnętrznego nie ustępowałaby zakładom karnym. Wydaje się, że najtaniej i najbardziej praktycznie byłoby wybudować tego typu placówki obok, a nawet w obrębie obecnie już funkcjonujących zakładów karnych. Zapewniono by przy tej okazji ochronę pracowników służby więziennej. Takie założenia wszakże z pewnością wywołają zarzuty, że w istocie nowy postpenalny środek zabezpieczajacy nie różniłby się niczym od kary pozbawienia wolności i umieszczone w ośrodkach terapii osobowości jednostki zostałyby faktycznie ukarane podwójnie za ten sam czyn.

Pojawia się również kolejna wątpliwość: Czy internacja oznaczałaby pozbawienie wolności, czy też znaczące jej ograniczenie? Czy byłyby to zakłady zamknięte, których umieszczeni tam ludzie nie mogliby opuścić, np. w celu udania się do pracy poza jego murami? Jeżeli tak, to w takim razie czym zajmowałyby się internowane tam osoby podczas całego, nierzadko długotrwałego pobytu? Czy państwo będzie w stanie zapewnić im jakąś pracę na terenie tego zakładu? Postanowienia nowelizacyjne nie zawieraja niestety uregulowań dotyczaccych tych zagadnień i trzeba to uznać za istotną ich wadę.

Należy tu również podkreślić, że kryterium, na podstawie którego osoby internowane mogłyby opuścić ośrodek terapii osobowości, nie powinno być łączone tylko z opinią biegłych psychiatrów. Przestępców poddawanych w zakładzie zamkniętym terapii zaburzeń osobowości należałoby zwalniać z internacji na podstawie pozytywnej opinii sformułowanej nie tylko przez lekarzy, lecz także specjalistów zajmujących się pracą wychowawcza, resocjalizacyjną i reedukacyjna z tymi osobami. Zatem opinie dla sądu w tym względzie mogliby formułować także np. wychowawcy oraz specjaliści z zakresu psychologii. Wydaje się też, że okres 6 miesięcy - proponowany w obu projektach noweli-

${ }^{24} \mathrm{~W}$ literaturze $\mathrm{z}$ zakresu psychologii oraz kryminologii zdania dotyczące ustalenia takiej granicy wiekowej sa podzielone. Jedni autorzy wskazuja, że prawdopodobieństwo popełnienia poważnych czynów karalnych przez osoby z osobowością dyssocjalną spada w przedziale pomiędzy 30 a 40 rokiem życia, inni wskazują na nieco późniejszy okres życia. Istnienie takiej prawidłowości jest tu wiązane z faktem, iż psychopaci i socjopaci później niż inni ludzie dojrzewają emocjonalnie i dopiero w wieku dojrzałym, w szerszym zakresie niż wcześniej zaczynają respektować obowiązywanie norm moralnych i prawnych. Por. w tym zakresie B. Pastwa-Wojciechowska, op. cit., s. 75; K. Pospiszyl, op. cit., s. 106-107; J. Szostak, Psychologia sqdowa. Podstawowe zagadnienia, Warszawa 2002, s. 145; K. Klimasiński, Elementy psychopatologii i psychologii klinicznej, Kraków 2000, s. 113-114. 
zacji - po którego upływie możliwe byłoby formułowanie prognozy kryminologicznej niebezpiecznego przestępcy, dotyczącej jego zachowania po opuszczeniu ośrodka, powinien być dłuższy i wynosić przynajmniej 1 rok, ponieważ zmiany w osobowości nie następują tak samo szybko, jak postępy w terapii chorób psychicznych.

Zwolnienie z ośrodka terapii osobowości mogłoby następować na próbę, w trakcie której realizowano by nadzór ochronny, przy czym okres tej próby zważywszy na wysoki stopień społecznego niebezpieczeństwa stwarzanego przez osoby zwalniane z internacji - powinien wynosić co najmniej 5 lat.

\section{PODSUMOWANIE}

Na podstawie przeprowadzonych tu rozważań można stwierdzić, że zasadniczym celem reformy sankcji karnych stosowanych względem sprawców najbardziej społecznie szkodliwych przestępstw, którzy wykazują zróżnicowane zaburzenia osobowości, powinno być zastapienie kary dożywotniego pozbawienia wolności systemem mieszanym, łączącym w sobie stosowanie długotrwałej kary pozbawienia wolności ze środkami zabezpieczającymi - wolnościowymi i izolacyjnymi. Realizacja tego typu środków lepiej służyłaby zapobieżeniu popełnienia nowych czynów karalnych przez takie osoby, niż długotrwała ich fizyczna izolacja społeczna w warunkach dożywotniego pozbawienia wolności. Część z osób internowanych zostałaby zwolniona z pobytu w zakładzie zabezpieczającym zapewne po stosunkowo krótkim okresie pobytu w nim, ale wtedy zostałaby objęta nadzorem podczas pobytu na wolności. Gdyby osoby takie zaczęły ponownie przejawiać zwiększone prawdopodobieństwo popełnienia nowego, poważnego przestępstwa, sąd mógłby zarządzić ich izolację ochronną. Istotnym wyzwaniem dla nauki prawa karnego powinno się stać ustalenie różnic pomiędzy warunkami pobytu w zakładzie karnym oraz w instytucjach, w których realizowany byłby izolacyjny środek zabezpieczajacy w stosunku do przestępców z zaburzoną osobowością. To samo tyczy się różnicy pomiędzy przesłankami warunkowego zwolnienia z zakładu karnego a podstawa prawną zwolnienia z internacji zabezpieczajacej.

dr Piotr Góralski

Uniwersytet Wroctawski

piotrgoralski@prawo.uni.wroc.pl 


\section{NOTES TO THE PROPOSED AMENDMENTS TO THE PENAL CODE CONCERNING PREVENTIVE MEASURES}

\section{Summary}

At the turn of 2012, the Ministry of Justice released two drafts of amendments to statutory regulations in criminal law, including the Mental Health Protection Act. The proposed amendments introduce new preventive measures to be applied with respect to personally disturbed perpetrators of the most severe crimes, after they have completed 25 years prison sentence. One of such measures involves placing such individuals in a special mental treatment facility, referred to as the personality treatment centre. Application of such measure is to be adjudicated by a custody court.

The author of this paper accepts the basic assumptions and objectives of the reform and makes critical evaluation of the specific amendment proposed. The main objections concern the premise that the new measure of an isolation type would not be used by a criminal court but a custody court, and the execution of this measure would be performed by an institution whose predominant role is to provide therapeutic treatment. 
Copyright of Journal of Law, Economics and Sociology is the property of Faculty of Law and Administration of Adam Mickiewicz University in Poznan and its content may not be copied or emailed to multiple sites or posted to a listserv without the copyright holder's express written permission. However, users may print, download, or email articles for individual use.

Właścicielem praw autorskich do „Ruchu Prawniczego, Ekonomicznego i Socjologicznego” jest Wydział Prawa i Administracji Uniwersytetu im. Adama Mickiewicza w Poznaniu. Zawartość czasopisma nie może być kopiowana, przesyłana do innych stron internetowych bądź zamieszczana na blogach bez pisemnej zgody wydawcy. Niemniej artykuły można drukować, kopiować lub przesyłać w formie elektronicznej na własny użytek. 